\title{
Conceptual underpinnings of focus-on-form in task-based language teaching
}

\begin{abstract}
Task-based language teaching (TBLT) which is often viewed as the strong version of Communicative Language Teaching (CLT) is gaining burgeoning interest as an approach to second language (L2) learning. However, many L2 researchers are concerned that the heavy focus on meaning and communication is insufficient for learners to achieve native-like language competence. Thus, researchers have proposed the use of focus-on-form in TBLT, where linguistic problems are dealt with as and when the need arises. This paper provides a conceptual basis for the need to use focus-on-form in TBLT in the L2 classroom.
\end{abstract}

Keyword: Focus-on-form; Task-based language teaching; L2 learners 